\title{
Effects of Austempering on the Microstructure, Corrosion and Mechanical Properties of AISI 1018 Steel
}

Oluwole Daniel Adigun ( $\sim$ oluwole.adigun@fuoye.edu.ng )

Federal University Oye-Ekiti

Muyideen Adebayo Bodude

University of Lagos

Aanuoluwapo Rebecca Adigun

Federal University Oye Ekiti

Babatunde Abiodun Obadele

Botswana International University of Science and Technology

Abdullahi Olawale Adebayo

Federal University Oye-Ekiti

Reginald Umunakwe

Federal University Oye-Ekiti

Funsho Olaitan Kolawole

Federal University Oye-Ekiti

Sunday Gbenga Borisade

Federal University Oye-Ekiti

\section{Research Article}

Keywords: Corrosion, austempering, heat-treatment, steel, microstructure, mechanical properties

Posted Date: September 3rd, 2021

DOI: https://doi.org/10.21203/rs.3.rs-861196/v1

License: (c) (i) This work is licensed under a Creative Commons Attribution 4.0 International License. Read Full License 


\section{Abstract}

In this study, the effects of austempering on the microstructure, mechanical properties (micro hardness, impact energy and tensile strength) and corrosion behaviours of AISI 1018 low carbon steel were evaluated. The steel specimens were subjected to heat treatment by austenitizing at $830^{\circ} \mathrm{C}$, maintained in this condition for 90 min before rapid cooling in a $\mathrm{NaNO}_{3}$ salt bath sustained at $300^{\circ} \mathrm{C}$ for isothermal transformation for additional 50 min and finally allowed to air cool to room temperature. The as-received and the austempered samples were tested for corrosion in both $0.5 \mathrm{M}$ aqueous acidic $(\mathrm{HCl})$ and $0.5 \mathrm{M}$ alkaline $(\mathrm{NaOH})$ media. Microstructural investigation using scanning electron microscope (SEM) reveals transformation from ferrite/pearlite phases to bainite over the austempering process. Interestingly, significant improvements of $15.7 \%$ to $95.7 \%$ in the various mechanical properties (micro hardness, impact energy and tensile strength) and corrosion resistance in both media were observed.

\section{Introduction}

AISI 1018 steel is a low carbon steel which is widely used in applications where exclusive materials attributes in mechanical properties and corrosion resistance cannot be compromised [1]-[3]. Mechanical properties of steel alloys can be improved via various metallurgical processes including cold working, hot working and heat treatment with heat treatment playing a dominant role. Various heat treatments methods have been used to achieve target properties in steels materials over time [4]-[6]. Austempering is an isothermal heat-treatment process which provides an alternative to quenching and tempering processes for optimizing the mechanical properties such as strength, toughness and tensile strength of steels for certain hardness levels. Besides its influence on mechanical properties, austempering may also influence the corrosion resistance of steels [7], [8]. Studies have also shown that heat treatment could also affect (to some extent) the ability of a material to conduct heat and electricity [9]-[11] .

Numerous studies have been done at improving the mechanical properties and resistance of low carbon steels to corrosion via various approaches with very few using the austempering heat treatment approach despite its potentials [12]-[14]. Hsu and Lin recently examined the effect of austempering and copper addition on the corrosion characteristics of ductile iron in a salty media (aqueous $\mathrm{NaCl}$ solution) and concluded that austempering mitigated the corrosion rate of the ductile iron specimen examined [15]. Similarly, a number of modern studies adopting the use of austempering on various iron materials have been published with fewer emphases on steel materials, showing that additional studies on the application of austempering at reducing the severity of corrosion attack on low carbon steels could be helpful in solving related problems [16], [17]. Metallurgical modification of material properties against corrosion however may consecutively impinge on both microstructure and mechanical properties and vice versa just as relationships between corrosion and its deteriorating effect on the mechanical properties of steels have been shown [18], [19].

This study seeks to evaluate the influence of austempering on the microstructure and mechanical properties of AISI 1018 and the successive effect on the corrosion resistance abilities of the resulting material.

\section{Materials And Methods}

The required materials such as AISI 1018 steel, nitrate salt, $\left(\mathrm{NaNO}_{3}\right)$ dilute hydrogen chloride $(\mathrm{HCl})$, sodium hydroxide solution $(\mathrm{NaOH})$ and distilled water were sourced locally and spectroscopic analysis of the AISI 1018 low carbon steel alloy was carried out using Positive Material Identification (PMI). 
The experiment design approach is as presented in Fig. 1. Two sets of the specimens (i.e. as-received specimen and austempered specimen) were prepared.

Austempering of the specimen was carried out by heating the specimens in a muffle furnace to a temperature of $830^{\circ} \mathrm{C}$, maintained at this temperature for a period of 90 min before isothermally cooled down in a $\mathrm{NaNO}_{3}$ salt bath at $300^{\circ} \mathrm{C}$ for $50 \mathrm{~min}$ and finally allowed to air cool to room temperature at a cooling rate of $3^{\circ} \mathrm{C} / \mathrm{min}$ as shown in Fig. 2 .

The microstructure of the as-received and austempered AISI 1018 steel alloys were analyzed by preparing about $50 \mathrm{x}$ $50 \mathrm{~mm}$ size of the two sets of specimens from the work piece and cleaned using ethanol in order to remove loosed particles, carbon or fat from the specimens surfaces to ensure adherence of the specimens with resin. The as-received and austempered AISI 1018 were placed in different moulds and liquid resin gently released into the moulds to about the same level before curing in the light curing unit for about 30 minutes to ensure polymerization of the resin with the embedded specimens. The surface of the specimens -as mounted in the polymerized resin- were further prepared by grinding; starting with 220 grits and up to 600 grits abrasive paper mounted on a water lubricated/flushed rotating disc. Polishing and etching were carried out in accordance with the ASTM E3 and ASTM E407 respectively. Afterwards, the specimens were loaded in the SEM (JSM-7600F model) and analysis carried out with an acceleration voltage of $20 \mathrm{kV}$ and magnifications of $1,400 \mathrm{X}$.

The tensile test was carried out in accordance with the ASTM A29 standard on the as-received and austempered samples using Instron Universal Testing Machine. Impact test was carried out in line with the ASTM E23 standard using the Avery- Denison Universal Impact Testing Machine while the Rockwell component of a BRIRO VA AUTOMAT (Automatic Hardness Testing Machine) was used for microhardness test using the ASTM E110 standard. The microhardness test was repeated five (5) times on different samples of both the as-received and austempered specimen and the average values adopted.

Corrosion test was carried out using weight loss in aqueous media approach. The specimens were cleaned and weighed in accordance with ASTM G1 before dipping in the $0.5 \mathrm{M}$ aqueous solutions of $\mathrm{HCl}$ and $\mathrm{NaOH}$ separately. The specimens were left in the aqueous solutions for three days after which they were removed, cleaned, dried and weighed. This was done every three days for a total of twenty-four days. The weight differences were calculated and used to determine the corrosion rates in the acidic and alkaline environments.

\section{Results And Discussion}

\section{Spectrometric Analysis}

Basically, AISI 1018 steel contains $98.00-99.00 \%$ iron (Fe) and $0.14-0.20 \%$ carbon (C) with $0.60-0.90 \%$ manganese $(\mathrm{Mn})$, about $0.04 \%$ phosphorous $(\mathrm{P})$ and $\leq 0.05 \%$ silicon $(\mathrm{Si})$ among others [20]. As presented in Table 1 , the chemical composition of the test specimen using the Positive Material Identification (PMI) falls within these ranges to confirm the test specimen. Steels with carbon content within the range of $0.05 \%-0.25 \%$ are generally mild or low carbon steels [21].

Table 1: Result of spectrometric analysis. 


\begin{tabular}{lllllllllll} 
Elements & $\mathrm{Ti}$ & $\mathrm{V}$ & $\mathrm{Cr}$ & $\mathrm{Mn}$ & $\mathrm{Ni}$ & $\mathrm{Cu}$ & $\mathrm{C}$ & $\mathrm{Co}$ & $\mathrm{P}$ & $\mathrm{Fe}$ \\
\hline $\begin{array}{l}\text { Contents } \\
(\%)\end{array}$ & 0.0006 & 0.0037 & 0.0723 & 0.7190 & 0.0634 & 0.1200 & 0.1870 & 0.0072 & 0.0150 & 98.4000 \\
\hline Elements & $\mathrm{S}$ & $\mathrm{Al}$ & $\mathrm{Si}$ & $\mathrm{Ca}$ & $\mathrm{Sn}$ & $\mathrm{Nb}$ & $\mathrm{Sb}$ & $\mathrm{Se}$ & $\mathrm{Mo}$ & $\mathrm{Zn}$ \\
\hline $\begin{array}{l}\text { Contents } \\
(\%)\end{array}$ & 0.0445 & 0.0007 & 0.2110 & 0.0028 & 0.0076 & 0.0019 & 0.0014 & 0.0022 & 0.0143 & 0.0131 \\
\end{tabular}

\section{Microstructural transformation}

Fig. 3 presents the microstructure of the AISI 1018 steel samples. The microstructure of the as-received specimen reveals a combination of naturally soft ferrite (gray grains) and pearlite (black grains) [22] as shown in Fig. 3a. The distribution of the ferrite and pearlite phases provide AISI 1018 low carbon steel a good combination of ductility, strength and toughness which makes it suitable for various fabrication processes like cold drawing, forging and machining [23].

During the austempering, the ferrite phases which is a solid solution of carbon (C) in the body-centered cubic (BCC) iron $(\mathrm{Fe})$ crystal structure and ordinarily stable at room temperature tends to gradually transform to a face-centered cubic (FCC) structure above the austenitizing temperature of $830^{\circ} \mathrm{C}$ (see points $A B, F i g .2$ ). Maintaining the $830^{\circ} \mathrm{C}$ temperature at $90 \mathrm{~min}$ (BC, Fig. 2) was intended to ensure dissolution and diffusion of the carbon atoms in the resulting FCC austenite phase. The rapid cooling/quenching in the salt bath maintained at $300^{\circ} \mathrm{C}$ was aimed at trapping the dissolved carbon atoms in the FCC austenite phase in order to prevent transformation back to BCC ferrite structure (see CD in Fig. 2). This resulted in a distorted crystal structure of a martensite (with body-centred tetragonal structure), that is ordinarily very hard, strong and brittle. Brittleness, however, isn't a desired property in most engineering applications because it is prone to mechanical failure [24]. Hence, the tempering process is maintained at $300^{\circ} \mathrm{C}$ for 50 min before finally allowed to cool slowly in air in order to allow for diffusion of the trapped carbon so that the crystal structure could be transformed to BCC to ensure increased ductility (see DE and DF in Fig. 2). As a consequence, internal stresses induced by the quenching process are relieved and the martensite carbon partitioning becomes transformed into the resultant bainite dominated microstructure as shown in Fig. 3b. Various steels suitable for specific applications are required to have bainitic microstructure and related purpose driven heat treatment studies have been carried out by researchers in recent time [25]-[28].

\section{Mechanical Properties}

Diffusion of the alloy elements (particularly carbon) within the as-received AISI 1018 steel structure during heating to $830^{\circ} \mathrm{C}$ and the subsequent trapping of the carbon atoms (during the isothermal cooling CD in Fig. 2) was aimed at a possible improvement in both hardness and strength [4] though with some level of brittleness resulting in between. While the tempering heat treatment initially maintained at $300^{\circ} \mathrm{C}$ for $50 \mathrm{~min}$ before cooling slowly at the rate of $3^{\circ} \mathrm{C} / \mathrm{min}$ in air was intended to ease internal stresses and improve ductility to reduce brittleness. The mechanical properties of the as-received and austempered AISI 1018 steel are presented in Fig. 4. Following microstructural transformation from the austempering process, the tensile strengths of the austempered specimen increased by $25 \%$ (Fig. 4c); micro hardness was observed to improve by $15.71 \%$ after the austempering process (Fig. 4a); and approximately $95.7 \%$ increase in impact energy resulted from the austempering (Fig. $4 \mathrm{~b}$ ).

\section{Corrosion Analysis}


Active alloy elements in the AISI 1018 steel include Fe (98.4000\%) Ca (0.0028\%), Al (0.0007\%), Sn (0.0076\%), Zn (0.0131\%), $\mathrm{Co}(0.0072 \%), \mathrm{Mn}(0.7190 \%), \mathrm{Cr}(0.0723 \%)$ and $\mathrm{Ni}(0.0634 \%)$. These active metals have tendencies to displace $\mathrm{H}^{+}$from the dilute $\mathrm{HCl}$ acid to form the chloride salts. Corrosion weight loss suffered by the AISI 1018 steel specimens (from the $0.5 \mathrm{M} \mathrm{HCl}$ acid species) was low within the first 3 days probably due to resistance provided by surface treatment during the steel production and also the formation of a relatively stable oxide protective film. Afterwards, the maximum weight loss in the acidic medium increased progressively until about 10 days of soaking before declining (Table 2 and Fig. 5a). The progressive increase in weight loss up to day 10 could be attributed to the breakdown of passive films and the spontaneous reaction of the active metals (alloy element) with the $\mathrm{H}^{+}$species from the acid and resultant removal and conversion of these alloy elements from the AISI 1018 steel surfaces to form the chloride salts (see Reaction 1). On the other hand, decrease in weight loss after the $10^{\text {th }}$ day may have resulted from re-passivation of the exposed surface of the steels, thus a reduction in the rate of $\mathrm{H}^{+}$activity as most of the $\mathrm{H}^{+}$ may have reacted with the active alloy elements to form thin films which indicates tendency towards the $1^{\text {st }}$ passivity domain. This $1^{\text {st }}$ passivity domain is observed to be a thin dark film layer formed on the surface of the specimen which may temporarily resist further corrosion attack. The thin film is liable to become weak from further corrosion weight losses due to defects on the thin film layer [29].

Reaction 1: $\quad$ (Alloy element) $(\mathrm{s})+\mathrm{HCl}_{(\mathrm{aq})} \rightarrow \mathrm{H}_{2(\mathrm{~g})}+($ Alloy element)Cl

Table 2: Corrosion weight loss in the acidic and alkaline media

\begin{tabular}{|lllll|}
\hline Days & $\begin{array}{l}\text { As-Received AISI 1018 } \\
\text { steel in HCl (g) }\end{array}$ & $\begin{array}{l}\text { Austempered AISI } \\
1018 \text { steel in } \mathrm{HCl}(\mathrm{g})\end{array}$ & $\begin{array}{l}\text { As-Received AISI 1018 } \\
\text { steel in NaOH (g) }\end{array}$ & $\begin{array}{l}\text { Austempered AISI 1018 } \\
\text { steel in NaOH (g) }\end{array}$ \\
\hline 1 & 0 & 0 & 0 & 0 \\
\hline 3 & 0.08 & 0.05 & 0.07 & 0.05 \\
\hline 7 & 1.09 & 0.89 & 0.09 & 0.08 \\
\hline 10 & 1.18 & 1.02 & 0.08 & 0.06 \\
\hline 17 & 1.06 & 0.97 & 0.06 & 0.05 \\
\hline 21 & 0.64 & 0.94 & 0.04 & 0.03 \\
\hline 24 & 0.5 & 0.54 & 0.02 & 0.02 \\
\hline
\end{tabular}

Relative to the weight loss observed in the as-received AISI 1018, the austempered steel specimen showed higher resistance to corrosion in the acidic medium. The relatively low losses through the 21-day evaluation may be attributed to better strength and enhanced hardness through the microstructural transformation of the austempered AISI 1018. Diffusion and the resultant trapping of the alloy elements during the heat treatment process may have increased the metallic bond within the steel lattice leading to reduction in the tendency of the alloy elements (metals) to react with the $\mathrm{H}^{+}$species from the $\mathrm{HCl}$ acid to form alloy/chloride salts. Hence, the relative corrosion weight loss of the heat treated (austempered) AISI 1018 is lower than that of the as-received AISI 1018 as shown in Fig. 6a (the red path)

\section{Corrosion in the alkaline medium}


As shown in Fig. $6 \mathrm{~b}$, corrosion weight loss in the $0.5 \mathrm{M} \mathrm{NaOH}$ solution was also very low within the first 3 days but increased rapidly afterwards till about 7 days before declining towards the $1^{\text {st }}$ passivity domain, with the maximum weight loss occurring at day 7 . However, the corrosion weight loss in the alkaline media is observed to reduce by up to a factor of $95 \%$ for both the as-received and austempered steel when compared to the acidic media (Fig. 6c). The drastic reduction in weight loss is not unusual because corrosion in acidic environments has been shown to be generally more severe than in alkaline media [30]. Unlike the activity of $\mathrm{H}^{+}$from the $0.5 \mathrm{M} \mathrm{HCl}$ on the alloy elements, the aqueous $\mathrm{NaOH}(0.5 \mathrm{M})$ species only interacts with a few of the alloy elements, i. e. $\mathrm{Zn}$ and Al to produce sodium tetrahydroxozincate, $\mathrm{Na}_{2}\left[\mathrm{Zn}(\mathrm{OH})_{4}\right]$ and sodium tetrahydroxoaluminate, $\mathrm{Na}\left[\mathrm{Al}(\mathrm{OH})_{4}\right]$ respectively. Hydrogen gas may be evolved in the process as shown below (see Reaction 2 and 3 ).

Reaction 2: $\quad 2 \mathrm{Al}_{(\mathrm{s})}+2 \mathrm{NaOH}_{(\mathrm{aq})}+6 \mathrm{H}_{2} \mathrm{O}_{(\mathrm{l})} \rightarrow 2 \mathrm{Na}\left[\mathrm{Al}(\mathrm{OH})_{4}\right]_{(\mathrm{aq})}+3 \mathrm{H}_{2(\mathrm{~g})}$

Reaction 3: $\quad \mathrm{Zn}_{(\mathrm{s})}+2 \mathrm{NaOH}_{(\mathrm{aq})}+2 \mathrm{H}_{2} \mathrm{O}_{(\mathrm{l})} \rightarrow \mathrm{Na}_{2}\left[\mathrm{Zn}(\mathrm{OH})_{4}\right]_{(\mathrm{aq})}+\mathrm{H}_{2(\mathrm{~g})}$

Diffusion and the resultant trapping of the alloy elements as well as increase in the interatomic bond over the heat treatment process leading to the improved mechanical properties of the austempered AISI 1018 specimen from the microstructural transformation also lead to a consequential reduction in the tendency of both $\mathrm{Zn}$ and Al alloys the react with the $\mathrm{NaOH}$ species in the alkaline media. Therefore, the austempered specimens had lower weight loss in the alkaline media relative to the as-received as shown in Fig. 6b (the red path)

\section{Conclusion}

Austempering heat treatment on AISI 1018 led to microstructural transformation from ferrite-pearlite microstructure to a bainite phase with improved mechanical properties (hardness, tensile strength and impact energy).

Exposure of both the as-received and austempered AISI1018 steel specimens to an acidic environment led to a harsh deterioration of the metal surfaces via chemical corrosion far beyond corrosion attack due to the alkaline environment. The improved corrosion resistance observed in the austempered AISI 1018 in both acidic and basic media may be attributed to the austempering. This shows that the austempering technique could be useful in the preparation of steel surfaces against corrosion attacks.

\section{Declarations}

Funding: The authors have no relevant financial or non-financial interests to disclose.

Conflicts of interest/Competing interests: The authors have no conflicts of interest to declare that are relevant to the content of this article.

Availability of data and material: The raw and processed data required to reproduce these findings are available to download from https://data.mendeley.com/datasets/88599bhfj4/1

Code availability: Not applicable

Ethics approval: The authors confirm that this article has not been submitted before for publication elsewhere and the content is original.

Consent to participate: The authors confirm participation as main, corresponding or co-authorship to publish this article 
Consent for publication: The authors confirm agreement to publish this article if accepted for publication

\section{References}

[1] O. Paul and M. Adel, "Erosion Mechanisms of API X42 and AISI 1018 Steel Materials at Normal Impact Angle," Int. J. Eng. Sci. Innov. Technol., vol. 3, no. 5, pp. 402-407, 2014.

[2] C. D. Reséndiz-Calderon et al., "Micro-Abrasion Wear Resistance of Borided 316L Stainless Steel and AISI 1018 Steel," J. Mater. Eng. Perform., vol. 26, no. 11, pp. 5599-5609, 2017.

[3] P. Kuppuraj et al., "Mechanical and Metallurgical Behaviours of Nitrided Aircraft Shaft," Int. J. Sci. Eng. Res., vol. 6, no. 9, pp. 1182-1185, 2015.

[4] M. Bodude, O. Adigun, and A. Ibrahim, "Microstructure and Mechanical Characterization of Austempered AISI 1018 Steel," FUOYE J. Eng. Technol., vol. 5, no. 1, pp. 102-105, 2020.

[5] N. M. Ismail, N. A. A. Khatif, M. A. K. A. Kecik, and M. A. H. Shaharudin, "The effect of heat treatment on the hardness and impact properties of medium carbon steel," IOP Conf. Ser. Mater. Sci. Eng., vol. 114, no. 1, pp. 0-9, 2016.

[6] G. Singh, "A review on effect of heat treatment on the properties of mild steel," in Materials Today: Proceedings, 2020, vol. 37, no. Part 2, pp. 2266-2268.

[7] M. Syaiful Anwar, Muzi, Saefudin, and E. Mabruri, "Effect of heat treatment process on hardness and hot corrosion resistance of Fe-25Ni-18Cr-1 Mo-2 W-1 Nb-Cast austenitic stainless steel," in Materials Today: Proceedings, 2020, vol. 44, pp. 3434-3438.

[8] Y. Zhao et al., "Influence of microstructure on the corrosion behavior of super 13Cr martensitic stainless steel under heat treatment," Mater. Charact., vol. 175, p. 111066, May 2021.

[9] C. Su, D. Li, T. Ying, L. Zhou, L. Li, and X. Zeng, “Effect of Nd content and heat treatment on the thermal conductivity of Mg-Nd alloys," J. Alloys Compd., vol. 685, pp. 114-121, Nov. 2016.

[10] M. Y. Hassaan, F. M. Ebrahim, A. G. Mostafa, and M. M. El-Desoky, "Effect of sulfur addition and heat treatment on electrical conductivity of barium vanadate glasses containing iron," Mater. Chem. Phys., vol. 129, no. 1-2, pp. 380-384, Sep. 2011.

[11] K. Li et al., "Microstructure evolution of eutectic Si in Al-7Si binary alloy by heat treatment and its effect on enhancing thermal conductivity," J. Mater. Res. Technol., vol. 9, no. 4, pp. 8780-8786, Jul. 2020.

[12] M. Balonis, G. Sant, and O. B. Isgor, "Mitigating steel corrosion in reinforced concrete using functional coatings, corrosion inhibitors, and atomistic simulations," Cem. Concr. Compos., no. CECO 3117, 2018.

[13] A. El Jaouhari et al., "Electrosynthesis of zinc phosphate-polypyrrole coatings for improved corrosion resistance of steel," Surfaces and Interfaces, vol. 15, pp. 224-231, 2019.

[14] J. Huang, C. Lou, D. Xu, X. Lu, Z. Xin, and C. Zhou, “Cardanol-based polybenzoxazine superhydrophobic coating with improved corrosion resistance on mild steel," Prog. Org. Coatings, no. June, p. 105191, 2019.

[15] C. H. Hsu and K. T. Lin, “Effects of copper and austempering on corrosion behavior of ductile iron in 3.5 Pct sodium chloride," Metall. Mater. Trans. A Phys. Metall. Mater. Sci., vol. 45, no. 3, pp. 1517-1523, 2014. 
[16] H. Krawiec, V. Vignal, J. Lelito, A. Krystianiak, and P. Ozga, "In-situ monitoring of the corrosion behaviour of austempered ductile iron (ADI) under cyclic salt spray exposure," Corros. Sci., vol. 185, p. 109437, 2021.

[17] O. J. Akinribide, S. O. Akinwamide, O. O. Ajibola, B. A. Obadele, S. O. oluwagbenga Olusunle, and P. A. Olubambi, "Corrosion behavior of ductile and austempered ductile cast iron in $0.01 \mathrm{M}$ and $0.05 \mathrm{M} \mathrm{NaCl}$ Environments.," Procedia Manuf., vol. 30, pp. 167-172, 2019.

[18] I. Fernandez and C. G. Berrocal, "Mechanical Properties of 30 Year-Old Naturally Corroded Steel Reinforcing Bars," Int. J. Concr. Struct. Mater., vol. 13, no. 1, p. 19 pages, 2019.

[19] Y. Hou, D. Lei, S. Li, W. Yang, and C. Q. Li, “Experimental Investigation on Corrosion Effect on Mechanical Properties of Buried Metal Pipes," Int. J. Corros., vol. 2016, p. 13 pages, 2016.

[20] AZoM, “AISI 1018 Mild / Low Carbon Steel,” azom.com, pp. 1-4, 2012.

[21] Key to Metals, "Classification of Carbon and Low-Alloy Steels," 1999. [Online]. Available: http://www.keytometals.com/Articles/Art62.htm. [Accessed: 19-Jul-2019].

[22] M. Nganbe, T. I. Khan, and L. B. and Glenesk, "High wear resistant HVOF coatings for use in the oil and sands industry," Symp. Mater. Technol. Mech. Eng., no. January 2006, 2006.

[23] AISI 1018, "Mild/Low Carbon Steel," Am. Iron Steel Inst. (AISI), Massachusetts Ave. NW, Washington, DC 20001, https//www.steel.org, pp. 1-4, 2015.

[24] A. Keramatian, A. Bahrami, A. H. Darougheh, and S. Zare, "Root cause analysis of an unexpected brittle failure in a carbon steel slab," Eng. Fail. Anal., vol. 122, p. 105205, 2021.

[25] E. Liu, Q. Li, S. Naseem, X. Huang, and W. Huang, "Effect of Isothermal Transformation Times below Ms and Tempering on Strength and Toughness of Low-Temperature Bainite in 0.53 C Bainitic Steel," Materials, vol. 13, no. 10. 2020.

[26] H. Guo, X. Feng, A. Zhao, Q. Li, and J. Ma, "Influence of Prior Martensite on Bainite Transformation, Microstructures, and Mechanical Properties in Ultra-Fine Bainitic Steel," Materials, vol. 12, no. 3. 2019.

[27] J. Zhao, J. Li, H. Ji, and T. Wang, "Effect of Austenitising Temperature on Mechanical Properties of Nanostructured Bainitic Steel," Materials, vol. 10, no. 8. 2017.

[28] M. Franceschi et al., "Effect of Different Austempering Heat Treatments on Corrosion Properties of High Silicon Steel," Mater. (Basel, Switzerland), vol. 14, no. 2, p. 288, Jan. 2021.

[29] D. Bai, F. Liu, H. Zhang, and J. Liu, "Corrosion behavior and passivation protection mechanism on different zone of high-nitrogen steel weld," Mater. Lett., vol. 300, pp. 130-194, 2021.

[30] S. Seethammaraju and M. Rangarajan, "Corrosion of stainless steels in acidic, neutral and alkaline saline media: Electrochemical and microscopic analysis," IOP Conf. Ser. Mater. Sci. Eng., vol. 577, p. 12188, 2019.

\section{Figures}




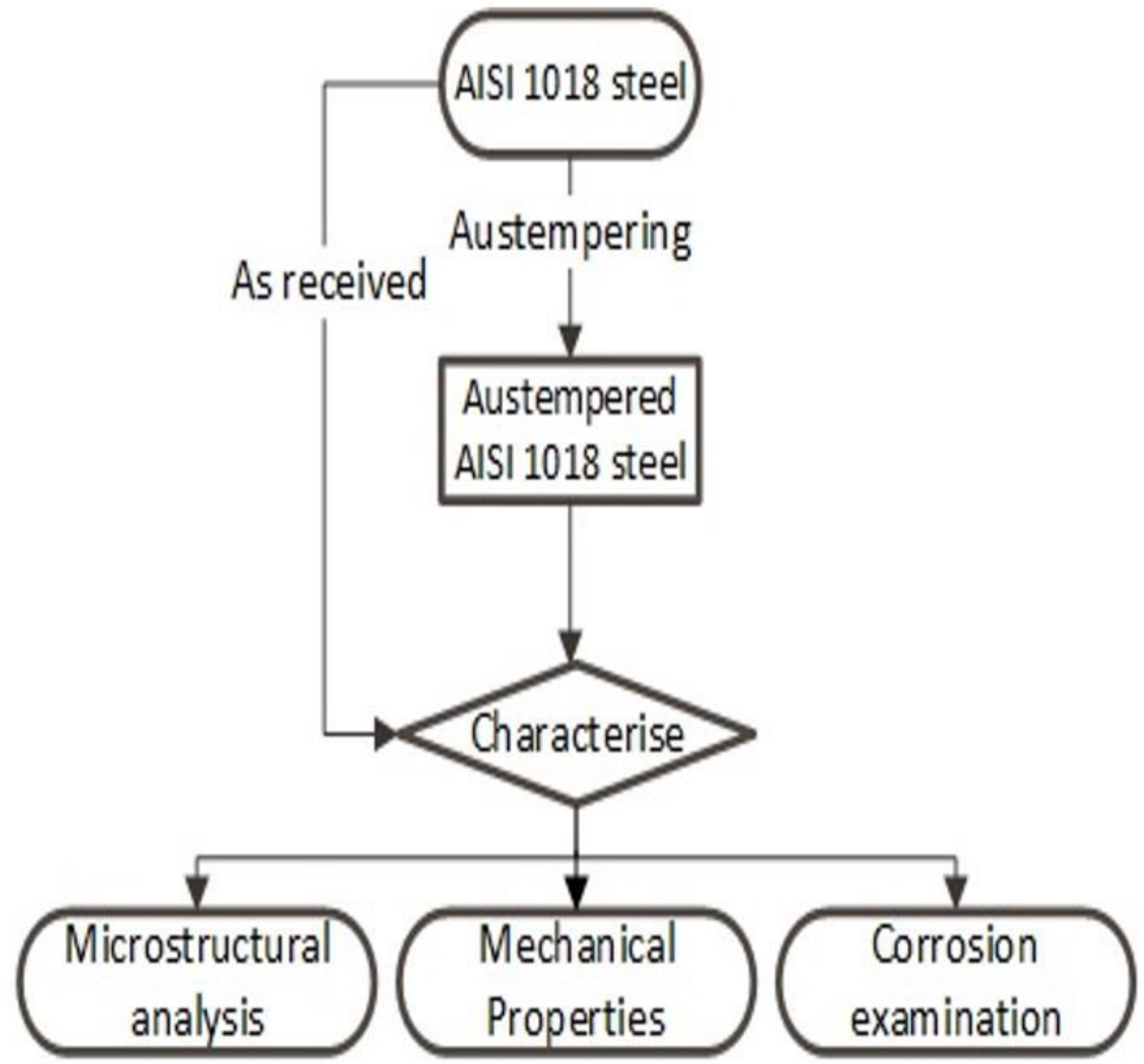

Figure 1

Experiment design process flow sheet. 


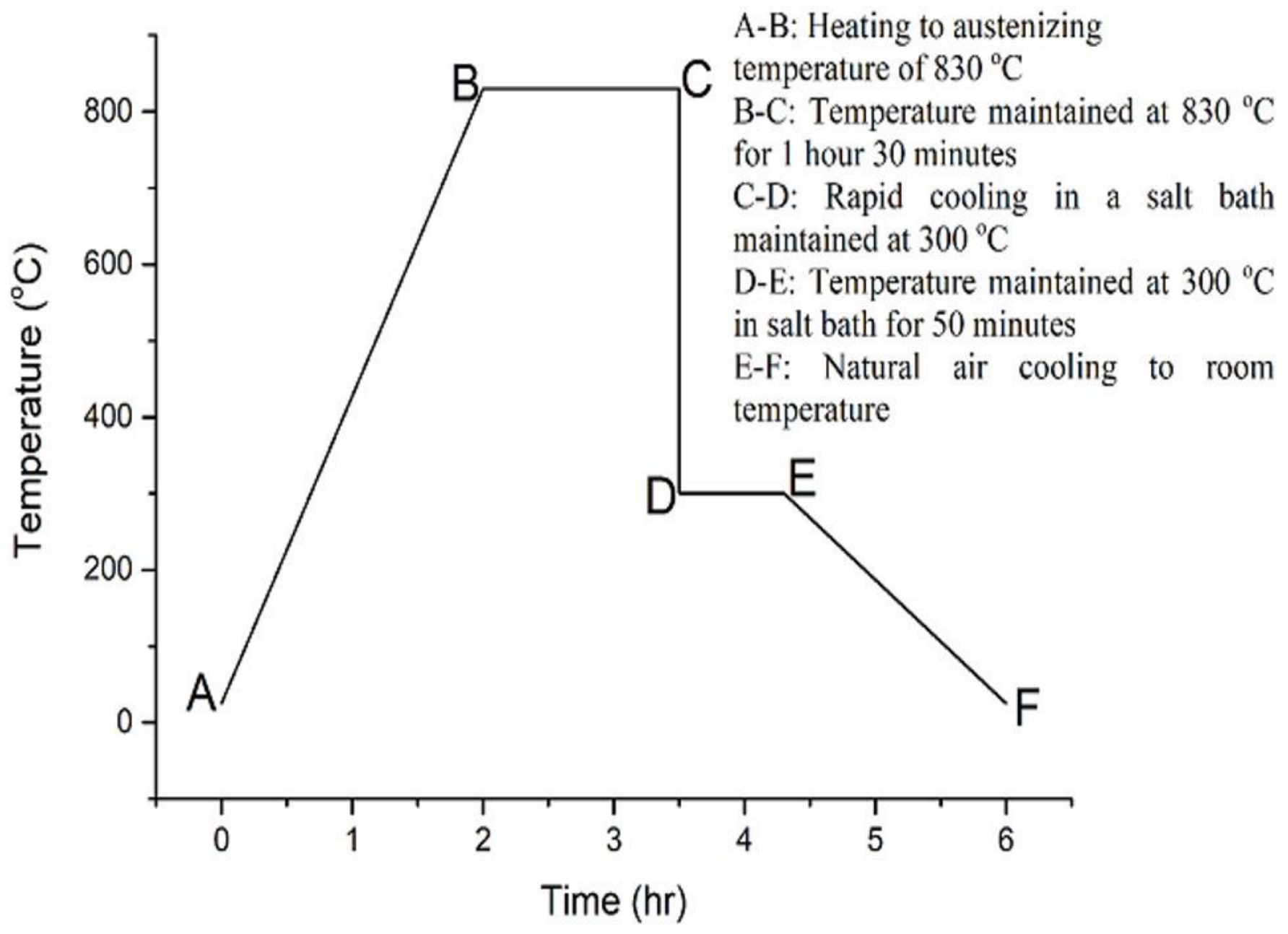

Figure 2

Schematic representation of the austempering process applied to the selected steel.
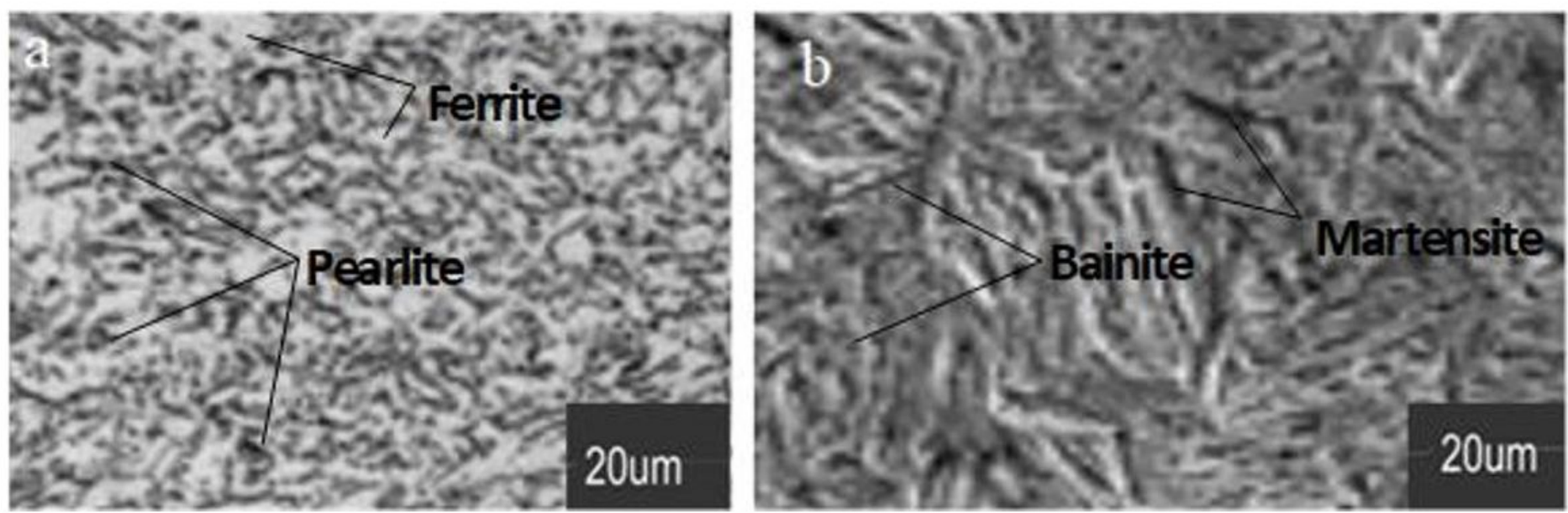

Figure 3

Microstructure of AISI 1018 steel sample (a) As-received AISI 1018 sample (b) Austempered AISI 1018 sample. 

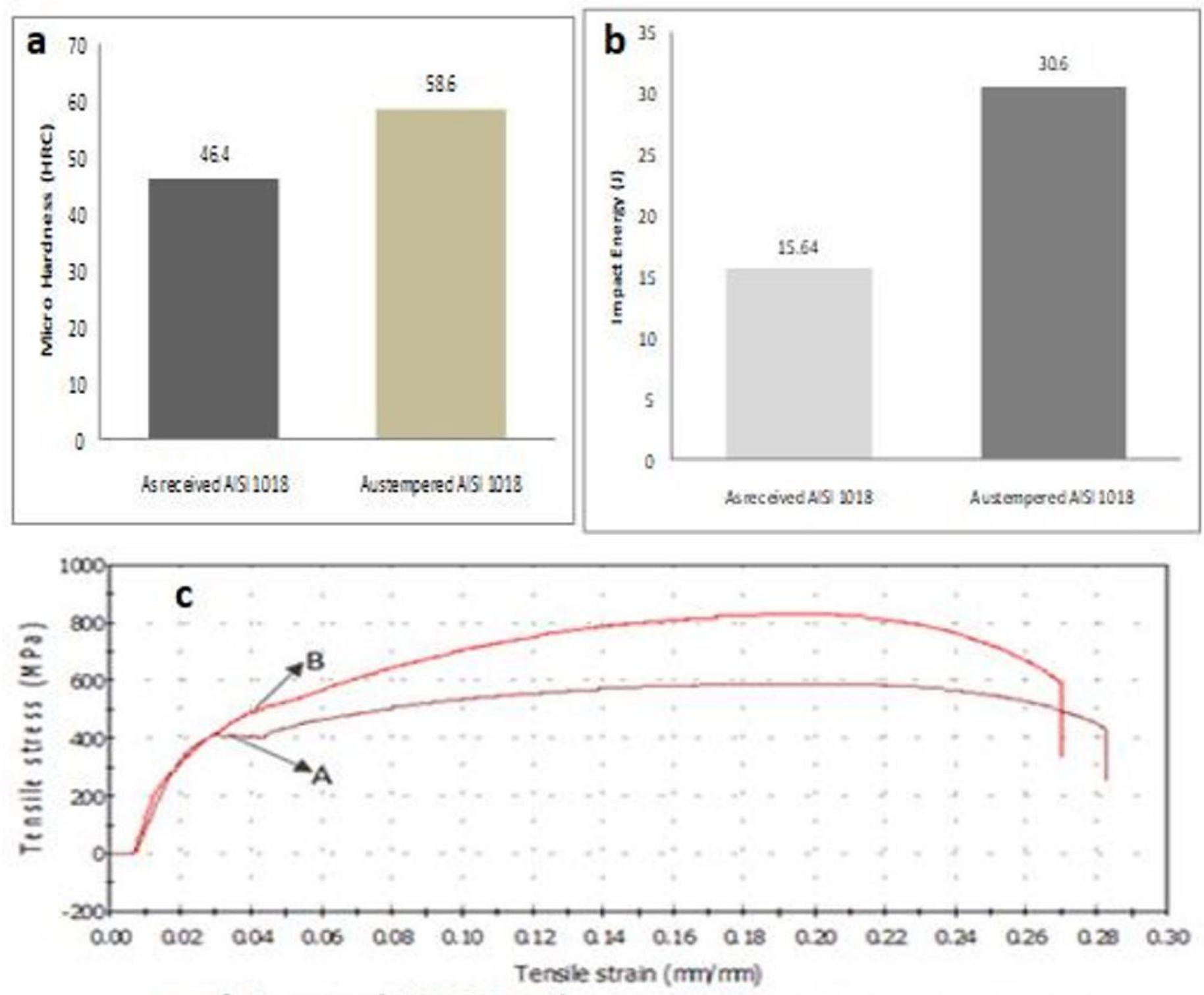

A As received AISI 1018 steel

B Austempered AISI 1018 steel

\section{Figure 4}

Mechanical properties of the as-received and austempered AISI 1018 steel (a) Micro-hardness (b) Impact energy and (c) Tensile strength. 


\section{Figure 5}

The maximum weight loss in the acidic medium increased progressively until about 10 days of soaking before declining.
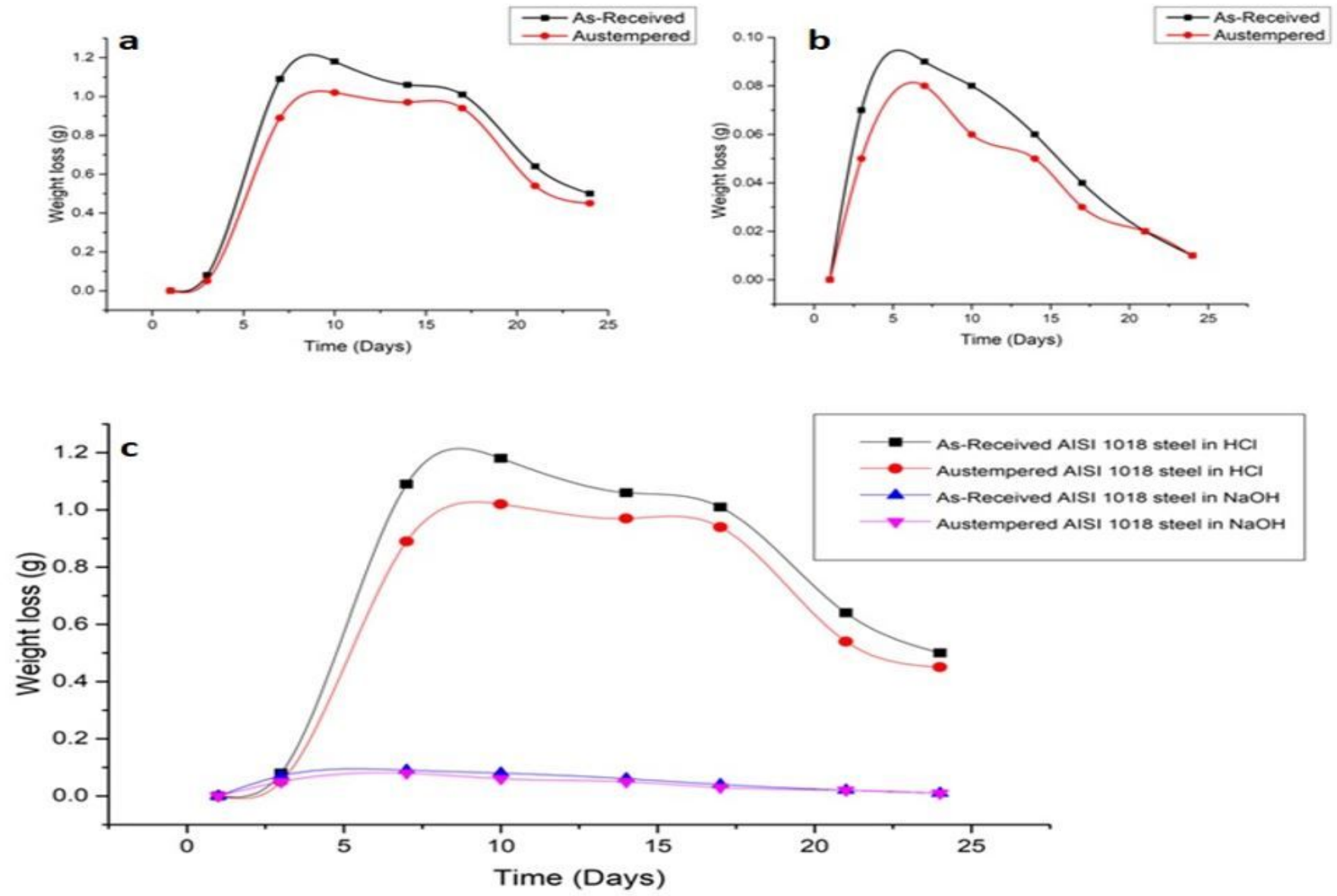

\section{Figure 6}

Weight loss vs. time for as-received and austempered AISI 1018 steel. (a) Acidic medium, $\mathrm{HCl}$ (b) Alkaline medium, $\mathrm{NaOH}$ (c) Both acidic and alkaline media 